\title{
Comparison of Renibacterium salmoninarum Isolates by Antigenic Analysis
}

\author{
R. G. Getchell, J. S. Rohovec, and J. L. Fryer \\ Department of Microbiology, Oregon State University, \\ Corvallis, Oregon 97331-3804
}

\begin{abstract}
Antigens of seven isolates of Renibacterium salmoninarum were compared serologically using immunoelectrophoretic techniques. Seven common components were identified by their electrophoretic mobilities in each antigenic profile. One of these common components designated antigen $\mathrm{F}$, was partially purified by ammonium sulfate precipitation and gel filtration. Cross adsorption analysis showed antigen $\mathrm{F}$ to be the major surface antigen of $R$. salmoninarum. This antigen was heat stable and its molecular weight was estimated by sodium dodecyl sulfate-polyacrylamide gel electrophoresis to be 57,000
\end{abstract}

\section{Introduction}

Bacterial kidney disease (BKD) causes losses among hatchery-reared salmonids throughout the world. Renibacterium salmoninarum, the kidney disease bacterium (KDB), is a slow-growing, Grampositive bacillus with an absolute requirement for cysteine (FRYER and SANDERS, 1981). Control of the disease by chemotherapy is difficult because of the bacterium's intracellular occurrence (Young and Chapman, 1978). Development of a prophylactic measure such as vaccination requires knowledge of the antigenic composition of $R$. salmoninarum. Antigenic relationships are also important because serological techniques form the basis for identification of $R$. salmoninarum by fluorescent antibody technique (Bullock et al., 1980; PATERSON et al., 1981). Early studies on the causative bacterium demonstrated one or more common antigens by immunodiffusion and cross agglutination (AUSTIN and RoDGERs, 1980; BULlock et al., 1974). However, comparative studies of the total antigenic profile of $R$. salmoninarum have not been performed.

The purpose of this work was to conduct a comparative study on the antigenic composition of selected $R$. salmoninarum isolates. The isolates were chosen for their wide geographical distribution and varied salmonid hosts. In addition, characterization of the major soluble antigen observed in serological tests was pursued. Selected immunoelectrophoretic techniques were used, including two-dimensional immunoelectrophoresis. Antigenic profiles were compared electrophoretically to determine common components. Cross adsorption analysis was performed to identify common surface antigens. This soluble antigen extracted from the type strain, Lea1-74 (ATCC 33209) (SANDERS and Fryer, 1980), was partially purified and its molecular weight determined.

\section{Materials and Methods}

Bacterial strains. Renibacterium salmoninarum isolates Lea-1-74 (ATCC 33209), KDV-10 pass 135, $\mathrm{K} 28, \mathrm{~K} 50, \mathrm{~K} 70, \mathrm{C}-384$, and $\mathrm{C}-37841$ were used as a source of antigens for immunizing and serological testing. Origins of the seven isolates studied are listed (Table 1). Lactobacillus piscicola B270 ATCC 35586 (Hiv et al., 1984) isolated from Salmo clarki brood trout was cultured in Tryptic Soy Broth and used as a negative control.

Preparation of immunogens. Renibacterium salmoninarum isolates Lea-1-74 and K50 were used as immunogens. Organisms were grown in a modified KDM-2 broth (M-KDM-2) which lacked the serum supplement ordinarily incorporated in this medium (Evelyn, 1977). Ferric sulphate $(0.0057 \mathrm{~g} / 100 \mathrm{~m} /)$ was added to the medium. Cultures were incubated at $18^{\circ} \mathrm{C}$ for 7 to 10 days in low form culture flasks with constant agitation. At the end of the in- 
Table 1. Sources of Renibacterium salmoninarum isolates used in this study

\begin{tabular}{|c|c|c|c|c|}
\hline $\begin{array}{c}\text { Antigen } \\
\text { designation }\end{array}$ & $\begin{array}{l}\text { Isolate } \\
\text { code }\end{array}$ & $\begin{array}{l}\text { Country of } \\
\text { origin }\end{array}$ & $\begin{array}{l}\text { Isolation } \\
\text { information }\end{array}$ & $\begin{array}{l}\text { Culture obtained } \\
\text { from }^{\mathrm{a}}\end{array}$ \\
\hline 1 & $\begin{array}{l}\text { Lea-1-74b } \\
\text { (ATCC 33209) }\end{array}$ & U.S.A. & $\begin{array}{l}\text { Oncorhynchus tshawytscha } \\
\text { Leaburg Hatchery }\end{array}$ & J. E. Sanders \\
\hline 2 & $\begin{array}{l}\mathrm{KDV}-10 \\
\text { pass } 135\end{array}$ & U.S.A. & $\begin{array}{l}\text { RB- } 1-73 \text { passed } 135 \text { times } \\
\text { on Mueller-Hinton plus } \\
0.1 \% \text { cysteine }\end{array}$ & J. S. Rohovec \\
\hline 3 & K28 & France & $\begin{array}{l}\text { Oncorhynchus kisutch } \\
\text { Eye }\end{array}$ & B. Austin \\
\hline 4 & K 50 & Norway & $\begin{array}{l}\text { Salmonids in sea } \\
\text { water cages }\end{array}$ & B. Austin \\
\hline 5 & $\mathrm{~K} 70$ & England & $\begin{array}{l}\text { Salmo gairdneri } \\
\text { Dermal blister }\end{array}$ & B. Austin \\
\hline 6 & C-384 & Canada & $\begin{array}{l}\text { Oncorhynchus kisutch } \\
\text { Quinsam Hatchery }\end{array}$ & G. S. Traxler \\
\hline 7 & $C-37841$ & Canada & $\begin{array}{l}\text { Oncorhynchus nerka } \\
\text { reared in sea water cages }\end{array}$ & G. S. Traxler \\
\hline
\end{tabular}

a Sources: J. E. Sanders and J. S. Rohovec, Department of Microbiology, Oregon State University, Corvallis, Oregon, U.S.A.; B. Austin, Fish Disease Laboratory, Weymouth, Dorset, England; G. S. Traxler, Pacific Biological Station, Nanaimo, British Columbia, Canada.

b Type strain of Renibacterium salmoninarum.

cubation period, the bacterial cells were centrifuged at $6000 \times g$ for $30 \mathrm{~min}\left(4^{\circ} \mathrm{C}\right)$. Supernatant fluid was saved for soluble antigen extraction, and the cells washed three times in $0.01 \mathrm{M}$ phosphate buffered saline, pH 7.2 (PBS). The pellet of cells from two $300 \mathrm{~m} /$ cultures was resuspended in $10 \mathrm{~m} / \mathrm{PBS}$ and disrupted by sonic treatment (four $30 \mathrm{~s}$ bursts, average watts $=50$ ) by a Sonifier Cell Disruptor (Heat Systems Ultrasonics, Plainview, N.Y.). This suspension was frozen at $-70^{\circ} \mathrm{C}$.

Preparation of antisera. A $2.2 \mathrm{~m} /$ mixture composed of equal volumes of immunogen and Freund's complete adjuvant (FCA) was injected subcutaneously between the scapulae $(1.4 \mathrm{~m} /)$ and in the footpads $(0.4 \mathrm{~m} /$ each) of a young, female New Zealand white rabbit. The rabbits were rested for 30 days then bled four times over the following five weeks. Eleven weeks post-immunization the rabbits were boosted with the same preparation. Ten days after the booster injection the rabbits were bled again. The serum was harvested and frozen in $4 \mathrm{~m} /$ aliquots at $-70^{\circ} \mathrm{C}$ until needed.

Preparation of antigens for serological tests. Organisms were grown, harvested, washed, and sonically treated following the same procedures as used for immunogen preparation. The soluble bacterial antigens present were cleared of cellular debris by centrifugation at $12,000 \times g$ for $30 \mathrm{~min}\left(4^{\circ} \mathrm{C}\right)$. The supernatant was then concentrated by ultrafiltration (Amicon YM-50, Lexington, MD) and the final protein concentration was measured by the method of BRADFORD (1976). The test reagent was obtained from Bio-Rad Laboratories (Richmond, CA). Cleared antigen suspensions were frozen at $-70^{\circ} \mathrm{C}$ until needed.

Immunodiffusion. The Ouchterlony immunodiffusion test was performed on GelBond film (Marine Colloids, Inc., Rockland, ME) adhered to glass plates. Antigens $(5 \mu l)$ and antisera $(10 \mu l)$ were placed in the wells and allowed to react in a moist chamber for $48 \mathrm{~h}\left(4^{\circ} \mathrm{C}\right)$. The dried gels were stained with $0.5 \%$ Comassie Brilliant Blue (w/v) and then photographed with background lighting using a macro lens and orange filter (THIRKILL and KENNY, 1974).

Immunoelectrophoresis. Immunoelectrophoresis was performed on large glass plates $(12 \times 12 \mathrm{~cm})$ covered with GelBond film. The supporting agarose matrix used in the following three methods was prepared as described by THIRKILL and KENNY 
(1974). Antigens $(5 \mu l)$ were placed in each $3 \mathrm{~mm}$ well and subjected to electrophoresis at $6 \mathrm{~V} / \mathrm{cm}$ for $45 \mathrm{~min}$. Antisera $(200 \mu l)$ was then added to the $2 \mathrm{~mm}$ wide trough, and precipitation arcs were allowed to form in a moist chamber for $48 \mathrm{hr}\left(4^{\circ} \mathrm{C}\right)$. Washing, staining, and photographing were performed as described previously.

Rocket immunoelectrophoresis. The plates, gels, and buffer used for rocket immunoelectrophoresis were the same as those used in the immunoelectrophoresis experiments, except only $20 \mathrm{~m} /$ of agarose per plate was required. The $5 \mathrm{~mm}$ wells containing antigen were punched out of the lower quarter of the gel. The upper three-quarters of this gel was removed and replaced with a gel containing $5 \%$ antisera $(\mathrm{v} / \mathrm{v})$. Antigens $(20 \mu l)$ were placed in each cathodic well and electrophoresis was performed at $1.5 \mathrm{~V} / \mathrm{cm}$ for $16 \mathrm{~h}$. Washing, staining, and photographing were performed as described.

Two-dimensional immunoelectrophoresis. The plates, gels, and buffer used for two-dimensional immunoelectrophoresis were the same as those used in rocket and immunoelectrophoresis experiments. The serological antigen $(20 \mu l)$ mixed with $10 \mu l$ of a $1 \mathrm{mg} / \mathrm{m} /$ solution of bovine serum albumin (Sigma, St. Louis, MO), which acted as a marker of the migration rate of each protein, was added to a $5 \mathrm{~mm}$ well cut out of the cathode corner of the gel plate. First dimension electrophoresis was carried out at $7.5 \mathrm{~V} / \mathrm{cm}$ for $1.5 \mathrm{~h}$. The upper portion of the gel $(3 / 4)$ was then removed and replaced with $15 \mathrm{~m} /$ of a $5 \%$ antibody-containing agarose mixture with $20 \mu \mathrm{l}$ of anti-BSA serum to reveal the BSA marker. The second phase was run at $1.5 \mathrm{~V} / \mathrm{cm}$ for $16 \mathrm{~h}$ at right angles to the electrophoretic direction of the first dimension. Washing, staining, and photographing were performed as described.

Cross adsorption procedures. The procedure for adsorption was that of O'LeARY et al. (1982). Briefly, a volume of antisera was added to an equal volume of wet packed cells, mixed, and allowed to incubate for $2 \mathrm{~h}$ at $30^{\circ} \mathrm{C}$ with periodic mixing. The cells were then pelleted by centrifugation at $6000 \times g$ for $15 \mathrm{~min}\left(4^{\circ} \mathrm{C}\right)$ and the remaining antisera was adsorbed two more times by the same method.

Rocket immunoelectrophoresis was used to screen this adsorbed antisera to determine which antigens were surface components. Wells $(5 \mathrm{~mm})$ were cut for each antigen in the lower quarter of the gel. The upper gel was replaced with agarose containing $5 \%$ adsorbed antiserum and the plate subjected to electrophoresis at $1.5 \mathrm{~V} / \mathrm{cm}$ for $16 \mathrm{~h}$. The results were recorded as previously noted with rocket immunoelectrophoresis.

Soluble Antigen Extraction. The supernatant fluid of $R$. salmoninarum cultures was raised to $50 \%$ saturation with ammonium sulfate $(297 \mathrm{~g} / l)$ and stirred overnight at $4{ }^{\circ} \mathrm{C}$. The precipitate was removed by centrifugation at $6000 \times g$ for $15 \mathrm{~min}$ $\left(4^{\circ} \mathrm{C}\right)$, suspended in $20 \mathrm{~m} / \mathrm{PBS}$, and dialyzed against $2 l$ of PBS overnight. The dialyzed protein extract was then concentrated to $4 \mathrm{~m} /$ by ultrafiltration over an XM-100A membrane (Amicon).

One crude antigen preparation (Lea-1-74) was fractionated on a Ultragel AcA 44 (LKB, Gaithersburg, MD) column $(1.7 \times 50 \mathrm{~cm})$ in $0.01 \mathrm{M}$ PBS ( $\mathrm{pH}$ 7.2). Samples were eluted using the same buffer and fractions collected. Each fraction was assayed for protein by measuring its absorbance at $280 \mathrm{~nm}$. Those fractions with high protein levels were assayed for soluble antigen by rocket immunoelectrophoresis. Fractions 21-30 were concentrated to $2 \mathrm{~m} /$ by ultrafiltration over an XM$100 \mathrm{~A}$ membrane (Amicon) and assayed by polyacrylamide-agarose gel two-dimensional immunoelectrophoresis and standard two-dimensional immunoelectrophoresis. The concentrated fractions, designated antigen $\mathrm{F}$, were also tested for heat stability by placing $1 \mathrm{~m} /$ of the concentrate at $100^{\circ} \mathrm{C}$ for $30 \mathrm{~min}$.

Polyacrylamide agarose gel two-dimensional immunoelectrophoresis. The molecular weight of the soluble antigens was determined by a combination of SDS-PAGE and two-dimensional immunoelectrophoresis (LAEMmLI, 1970). Prior to SDS-PAGE, the antigen samples were boiled for $2 \mathrm{~min}$ in buffer containing $10 \%$ SDS (w/v) and $1.25 \% 2$-mercaptoethanol $(\mathrm{v} / \mathrm{v})$. The molecular weight (MW) of the antigen was determined by comparison to a mixture of low MW markers (Bio-Rad) loaded between two antigen wells. Electrophoresis was performed at a constant $10 \mathrm{ma}$ in the stacking gel and $20 \mathrm{ma}$ in the separating gel until the tracking dye reached the bottom of the gel. The gel was sliced vertically, and the MW marker lane and one antigen lane were 
stained for proteins. The other gel strip containing the second antigen lane was transferred to a GelBond film-covered plate and $15 \mathrm{~m} /$ of melted $5 \%$ antibody-containing agarose was added to the upper portion of the plate. The gel was subjected to electrophoresis in the second dimension at $1.5 \mathrm{~V} / \mathrm{cm}$ for $16 \mathrm{~h}$. Washing and staining were performed as described previously. The position of the protein bands in the first dimension was compared with the position of the precipitation peak of the soluble antigen in the second dimension.

\section{Results}

Immunodiffusion. The precipitin bands demonstrated by double diffusion analysis showed identity between the antigens of each $R$. salmoninarum isolate (Fig. 1). Canadian isolates 384 and 37841 showed fainter precipitin lines because of a lower total antigen concentration.

Immunoelectrophoresis. Soluble antigens of $R$. salmoninarum were analyzed by immunoelectrophoresis (Fig. 2). Each isolate showed a common component with a well defined arc and a broad migration rate. An extracted soluble antigen (anti-

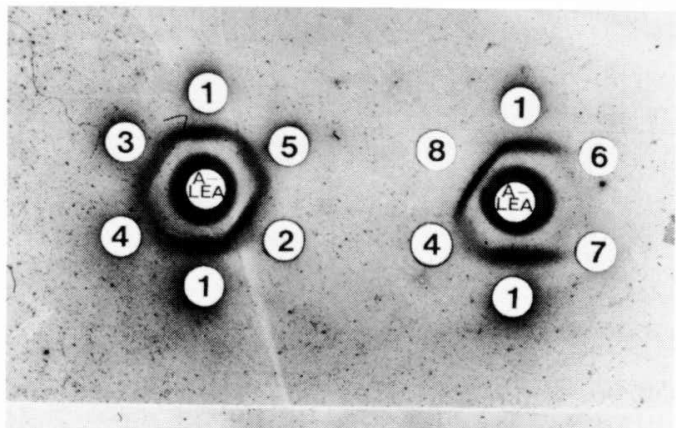

Fig. 1. Ouchterlony immunodiffusion analysis of Renibacterium salmoninarum soluble antigens. Center wells contain rabbit antisera prepared against either isolate Lea-1-74 or K50. Outer wells contain a serological test antigen or the extracted soluble antigen ( $F$, well number 8$)$. See Table 1 for serological antigen designations.

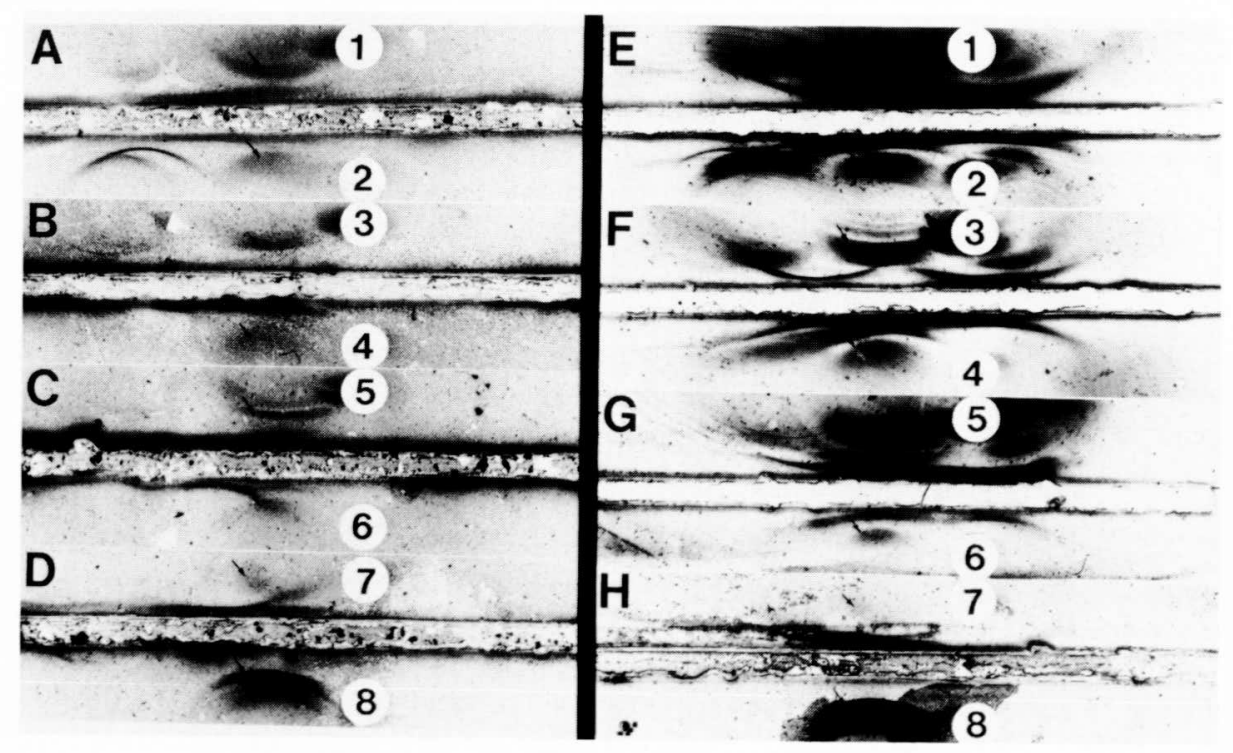

Fig. 2. Immunoelectrophoresis of Renibacterium salmoninarum soluble antigens. Center troughs contain rabbit antisera prepared against either isolate Lea-1-74 or K 50 . Wells contain a serological test antigen or an extracted soluble antigen ( $\mathrm{F}$, well number 8). See Table 1 for serological antigen designations. A, B, C, and D contain Lea-1-74 antiserum. E, F, G, and H contain K50 antiserum. Arrows show the common soluble antigen. 
gen F) from isolate Lea-1-74 was precipitated in the same position as the common component present in the other immunoelectrophoresis runs.

Rocket immunoelectrophoresis. Electrophoresis of soluble antigens from KDB isolates into rabbit antiserum, prepared against isolates Lea-1-74 and $\mathrm{K} 50$, resulted in 7 to 15 distinct peaks (Fig. 3). Rocket immunoelectrophoresis of Lea-1-74 or K 50 antigens against preimmune sera was performed to determine whether the rabbit possessed antibodies to $R$. salmoninarum antigens prior to immunization. No precipitin lines were observed. Antigen contamination by medium components (M-KDM-2) was also tested by rocket immunoelectrophoresis against antisera to Lea-1-74 and K 50. Lactobacillus piscicola, another Gram-positive fish pathogen, was used to detect cross reacting antigens. Rocket immunoelectrophoresis of M-KDM-2 and antigens from $L$. piscicola against anti-Lea-1-74 serum revealed no precipitin lines.

Two-dimensional immunoelectrophoresis. All serological antigen preparations from $R$. salmoninarum isolates were tested by two-dimensional immunoelectrophoresis with anti-Lea-1-74 and antiK50 sera (Fig. 4). Eight to twenty precipitin peaks were observed with each isolate, depending on relative antigen concentrations and antiserum potency. The number of precipitin peaks formed by each isolate was compared. Anti-K 50 serum produced a profile with the type strain, Lea-1-74, which closely resembled that obtained with the homologous isolate (K50). Profiles shown by Lea-1-74 antiserum were also similar in shape, position, and intensity of the stained peaks to anti-K 50 serum profiles. Fewer components were detected with isolates $\mathrm{K} 28$ and $\mathrm{K} 70$ against anti-K 50 serum, but the profiles appeared the same. Similarly, the Canadian isolates, 384 and 37841 , produced fewer peaks, but the antigens that were present corresponded with the major peaks of the other isolates examined in this manner.

The further comparison of precipitation arcs formed by each isolate required determination of the relative electrophoretic mobilities. Each antigen could be clearly identified by its relative migration rate versus the migration distance of the bovine serum albumin (BSA) marker, which was assigned a value of 1.0. Relative mobilities measured ranged

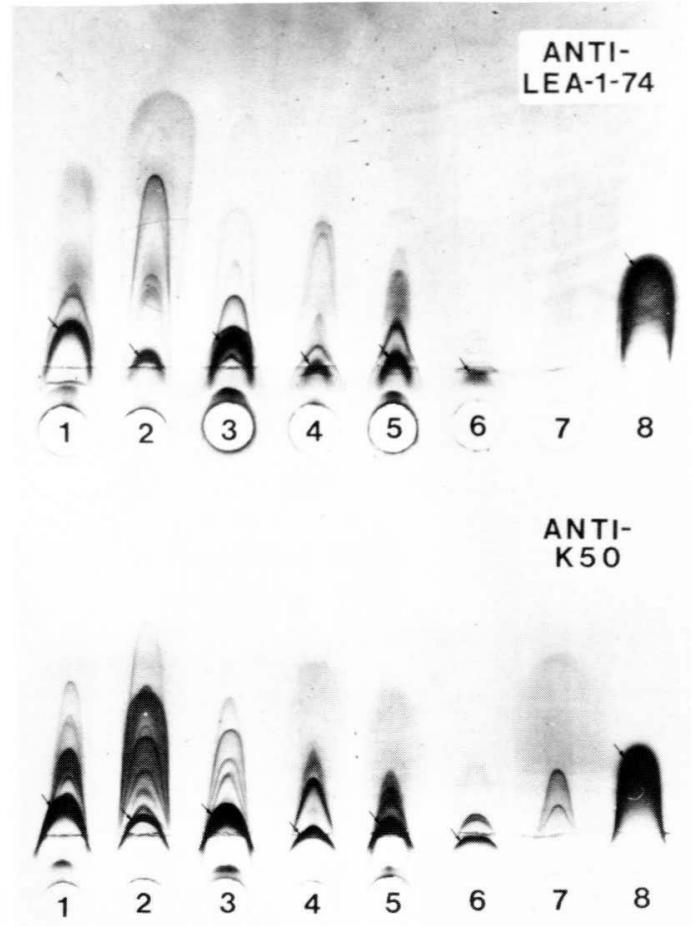

Fig. 3. Rocket immunoelectrophoresis of Renibacterium salmoninarum soluble antigens. The top portion of agarose contains $5 \%$ antiserum prepared against either isolate Lea-1-74 or $\mathrm{K} 50$ as indicated. The cathodic wells contain serological test antigens and an extracted soluble antigen ( $F$, well number 8 ). See Table 1 for serological antigen designations.

from -0.19 to +1.87 . The mobilities, electrophoretic order, and relative size of peaks were reproducible and similar between runs.

Seven common components were identified with anti-K50 serum (Table 2). Three of these seven components (A, D, and F) matched the common peaks resolved with antiserum to Lea-1-74. The relative mobilities of these antigens were used to label their respective peaks (Fig. 4). Those distinct peaks not labelled were clustered too close to each other to determine if they were common or unique components.

Cross adsorption analysis. Antisera adsorbed with whole cell preparations of $R$. salmoninarum were screened by rocket immunoelectrophoresis (Fig. 5). These results indicated that the soluble antigen extracted from Lea-1-74 (antigen F) was a common 

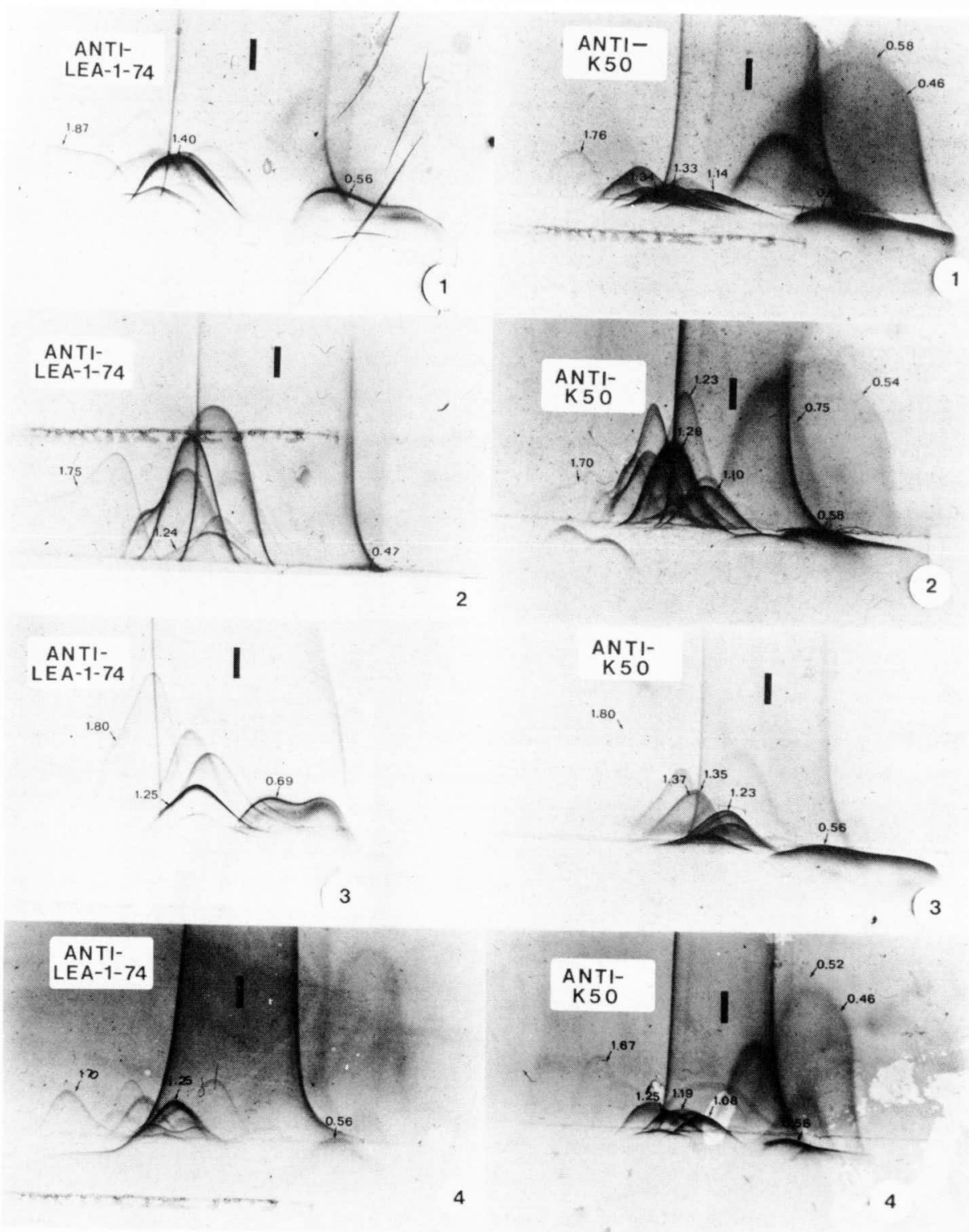

Fig. 4. Continued on next page.

surface component present on each isolate. This was demonstrated when anti-Lea-1-74 serum was adsorbed with either its homologous antigens or those of K50 and this intense antigen peak disappeared (Fig. 5). The majority of peaks did not disappear or increase substantially in height, showing that these antigens were either located in the cytoplasm or are nonexposed membrane associated antigens. Peaks that did not disappear, but increased in height may have been surface antigens which were not totally adsorbed.

Characterization of an extracted soluble $K D B$ antigen. The immunodiffusion analysis of extracted antigens showed that $R$. salmoninarum isolates produced a major soluble component immunologically identical and common to each isolate (Fig. 6). Rocket immunoelectrophoresis of extracted antigens revealed a bullet-shaped peak with anti-K 50 and anti-Lea-1-74 serum (Fig. 6). Minor peaks were 

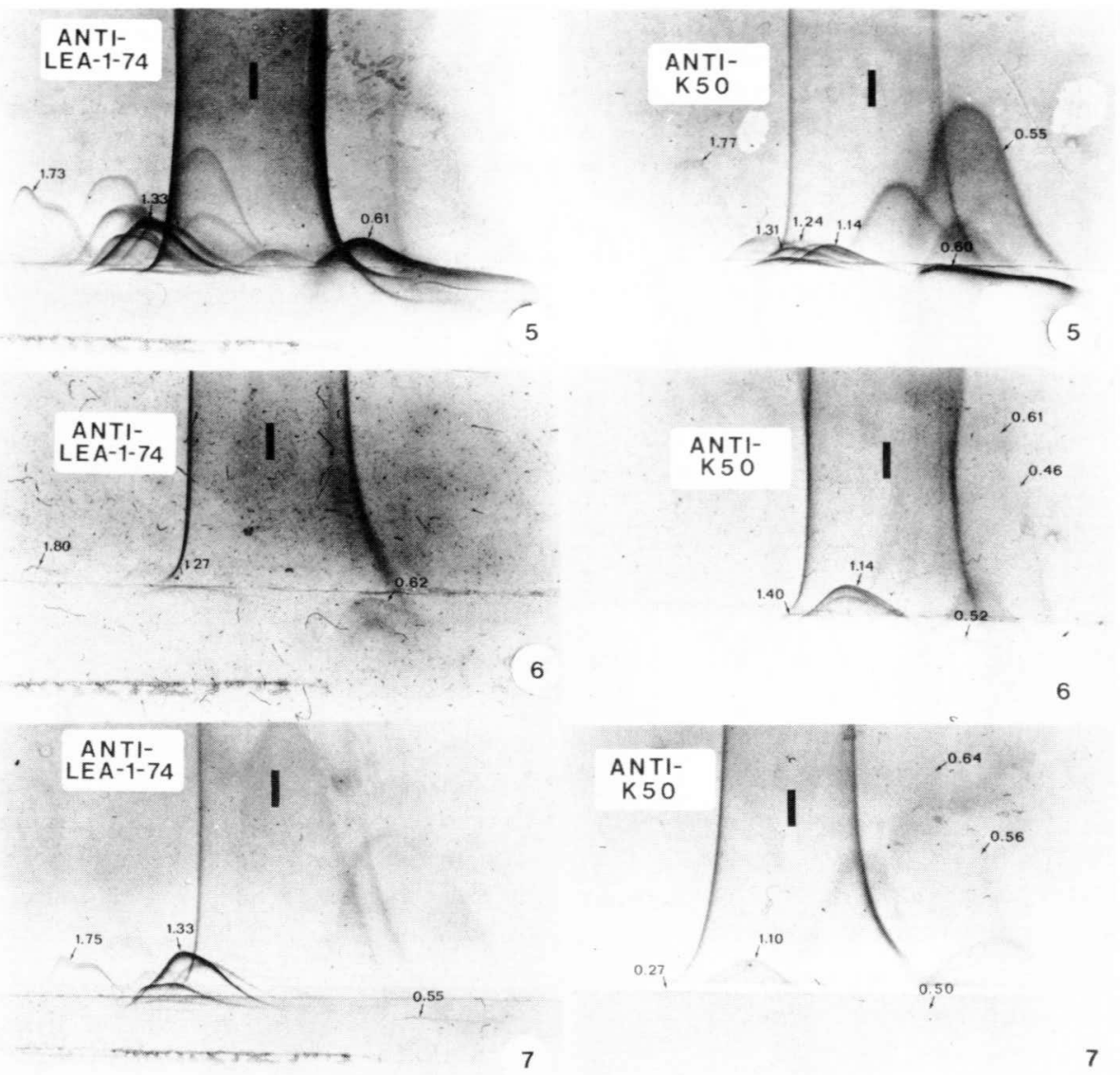

Fig. 4. Two-dimensional immunoelectrophoresis profiles of Renibacterium salmoninarum isolates. The top portion of agarose contains 5\% antiserum prepared against either isolate Lea-1-74 or K 50 as indicated. The cathodic wells contain the serological test antigens (see Table 1 for designations). Common components are identified with their electrophoretic mobilities relative to bovine serum albumin (vertical bar, upper left).

also evident. Crude extracted antigen from one isolate (Lea-1-74) was fractionated by gel filtration, and fractions containing high protein levels were assayed by rocket immunoelectrophoresis. Fractions 21-30 showed strong precipitin reactions and were pooled.

Fractions 21-30 (antigen F) were concentrated and assayed by two-dimensional immnoelectrophoresis. Anti-K50 serum resolved a single peak with an electrophoretic mobility of 0.56 , while antiLea-1-74 serum showed a peak with the same relative mobility and a second ill-defined arc which shadowed the other peak. This same double peak effect was seen with crude extracted Lea-1-74 (Fig.
6C, well 1) and rocket immunoelectrophoresis of antigen $\mathrm{F}$ (Fig. 3A, well 8).

Polyacrylamide-agarose gel two-dimensional immunoelectrophoresis of the concentrated fractions (antigen $\mathrm{F}$ ) detected a precipitin reaction in the second dimension that matched the protein bands in the first dimension (Fig. 7). The estimated molecular weight of the major distinct band was 57,000 based on SDS-PAGE electrophoresis. An immunologically homogeneous protein mixture was present above and below this $57 \mathrm{~K}$ band (Fig. 7). Antigen $\mathrm{F}$ was also found to be heat stable at $100^{\circ} \mathrm{C}$ for $30 \mathrm{~min}$. 
Table 2. Common components of Renibacterium salmoninarum isolates as detected by two-dimensional immunoelectrophoresis

\begin{tabular}{|c|c|c|c|c|c|c|c|}
\hline \multirow{2}{*}{ Antigen } & \multicolumn{7}{|c|}{$\begin{array}{l}\text { Relative electrophoretic mobility of common } \\
\text { components in } R \text {. salmoninarum isolates }\end{array}$} \\
\hline & Lea-1-74 & KDV-10 & $\mathrm{K} 28$ & K 50 & K 70 & 384 & 37841 \\
\hline \multirow[t]{2}{*}{ A } & $1.76^{\mathrm{a}}$ & 1.70 & 1.80 & 1.67 & 1.77 & - & - \\
\hline & $(1.87)^{\mathrm{b}}$ & $(1.75)$ & $(1.80)$ & $(1.70)$ & $(1.73)$ & $(1.80)$ & (1.75) \\
\hline $\mathrm{B}$ & 1.34 & 1.26 & 1.37 & 1.25 & 1.31 & 1.40 & 1.27 \\
\hline $\mathrm{C}$ & 1.33 & 1.23 & 1.35 & 1.19 & 1.24 & - & - \\
\hline \multirow[t]{2}{*}{ D } & 1.14 & 1.10 & 1.23 & 1.08 & 1.14 & 1.14 & 1.10 \\
\hline & $(1.40)$ & $(1.24)$ & $(1.25)$ & $(1.25)$ & $(1.33)$ & $(1.27)$ & $(1.33)$ \\
\hline $\mathrm{E}$ & 0.58 & 0.75 & - & 0.52 & - & 0.61 & - \\
\hline \multirow[t]{2}{*}{$\mathrm{F}$} & 0.60 & 0.58 & 0.56 & 0.56 & 0.60 & 0.52 & 0.50 \\
\hline & $(0.56)$ & $(0.47)$ & $(0.69)$ & $(0.56)$ & $(0.61)$ & $(0.62)$ & (0.55) \\
\hline G & 0.46 & 0.54 & - & 0.46 & 0.55 & 0.46 & 0.56 \\
\hline
\end{tabular}

a The numbers given represent mobilities detected by anti-K50 serum.

b The numbers enclosed represent mobilities detected with anti-Lea-1-74 serum.

\section{Discussion}

Antigenic analysis showed all $R$. salmoninarum isolates tested to be closely related serologically. This is in agreement with earlier reports indicating

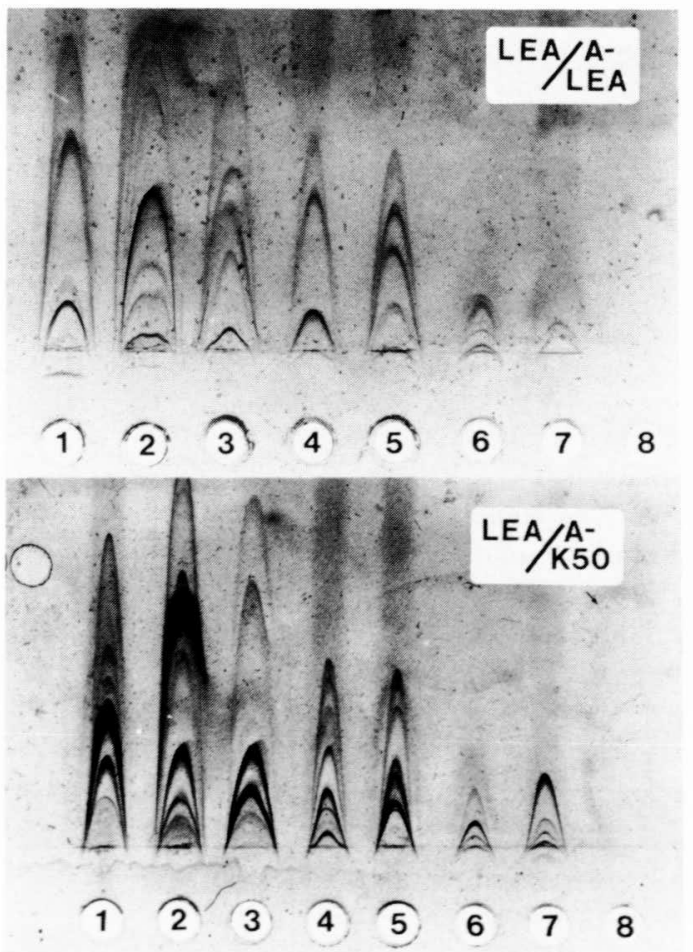

serological homogeneity (BULLOCK et al., 1974; PATERSON et al., 1981); however, the present study used methods with increased sensitivity, therefore more antigens were analyzed. Using rocket and two-dimensional immunoelectrophoresis, electrophoretically common components could be identified by their similar mobilities, position among other peaks, peak shape, and staining intensity. Some components were not analyzed because their peaks were either too faint or too close to neighboring peaks to be identified consistently as common or unique. Though approximately one-half of the total antigens of each isolate were not analyzed, the common components that were identified formed densely staining peaks indicative of high antigen concentration. In their antigenic analysis of Mycoplasma arginini, THIRKILL and KENNY (1974) studied only one-third of the total antigens (20 in all) present in each of three strains. However, the major, densely staining peaks, were analyzed which

Fig. 5. Rocket immunoelectrophoresis of anti-Lea-174 and anti-K 50 sera following adsorption with Renibacterium salmoninarum isolates. The top portion of agarose contains $5 \%$ antiserum adsorbed with the isolate indicated (adsorbing isolate/antiserum). The cathodic wells contain serological test antigens and an extracted soluble antigen ( $F$, well number 8 ). See Table 1 for antigen designations. See Fig. 3 for unadsorbed, control illustrations. 

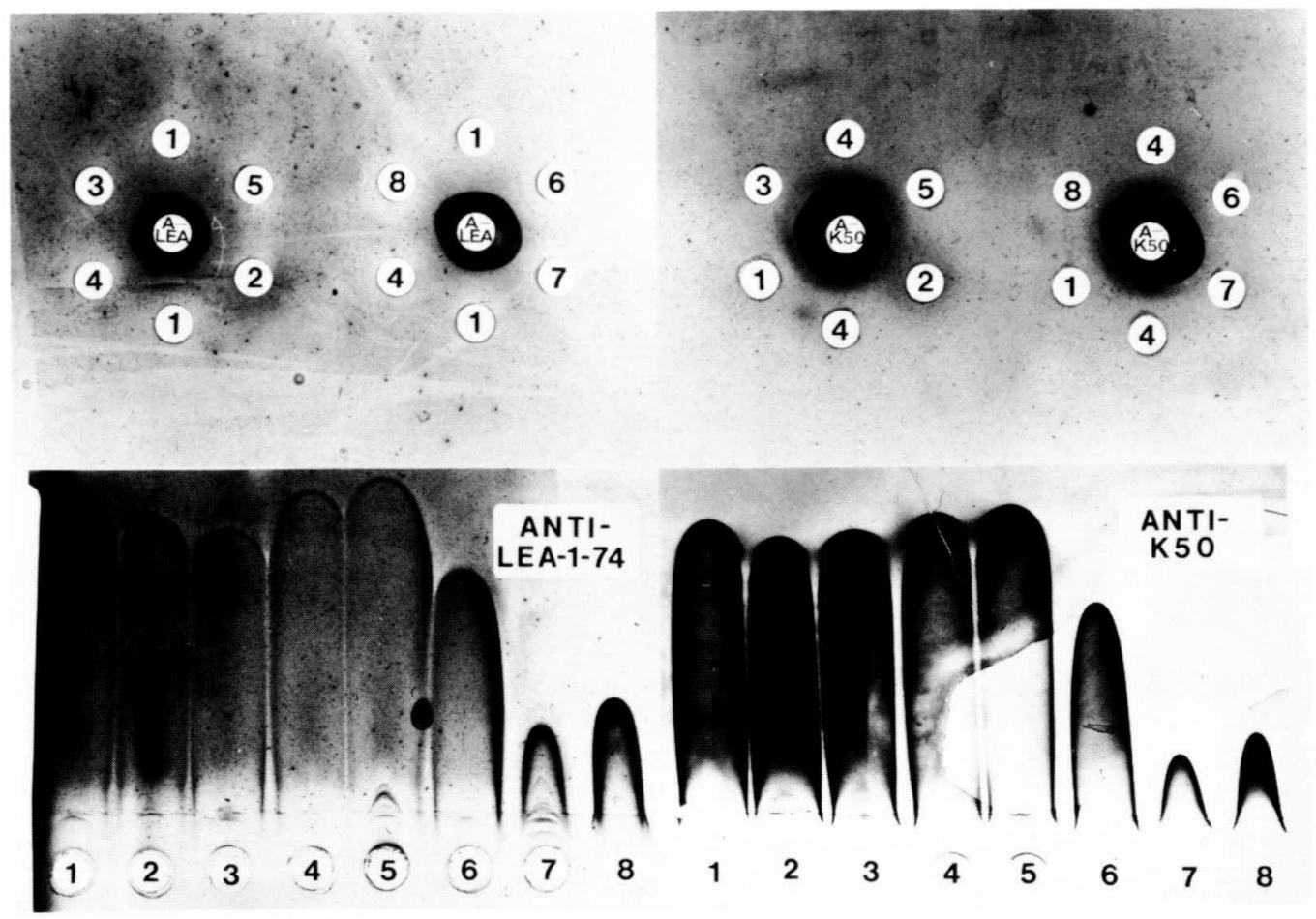

Fig. 6. Ouchterlony immunodiffusion and rocket immunoelectrophoresis of crude extracted antigens from Renibacterium salmoninarum isolates. Center wells and the top portion of agarose contain rabbit antisera prepared against either isolate Lea-1-74 or K50 as indicated. Outer and cathodic wells contain extracted soluble antigens from each isolate, including antigen $\mathrm{F}$ (well number 8). Extracted soluble antigens are denoted with the same numbers as those used for serological test antigens (Table 1).

enabled antigenic relationships to be shown within the species. The present study demonstrated the presence of seven common components which represent the major concentration of antigens for each $R$. salmoninarum isolate. In addition, one of these common components $(\mathrm{F})$ was shown to be a major surface antigen by cross adsorption analysis.

The nature of these resolved antigens is unknown except for the extracted antigen $(F)$. Other membrane components were perhaps solubilized by the nonionic detergent Triton-X-100, though they may have been internally bound antigens not detected by adsorption studies. Antigen $\mathrm{F}$ was shown to have a consistent electrophoretic mobility of approximately 0.56 in all isolates tested. The SDS-PAGE showed that there are components in antigen $\mathrm{F}$ of differing molecular weights, which may help explain why a shadow or double peak was seen whenever antigen $F$ reacted with anti-Lea-1-74 serum.
Because antigen $\mathrm{F}$ was the major soluble antigen extracted from spent culture medium and a major surface component, it is probably one of the same soluble antigens detected by immunodiffusion (Bullock et al., 1974; CHEN et al., 1974). In addition, antigen $\mathrm{F}$ was found to be stable to heating at $100{ }^{\circ} \mathrm{C}$ for $30 \mathrm{~min}$, so antigen $\mathrm{F}$ is probably the same heat stable antigen extracted from KDB cells and infected kidneys by Kimura et al. (1978).

Antigenic analysis of $R$. salmoninarum isolates showed that seven major antigens with distinct mobilities could be identified. The first of these common components characterized proved to be serologically identical in every isolate tested. Future research should be directed toward characterization of the other components observed in this study to determine their antigenic relatedness. More elaborate techniques such as tandem or intermediate gel crossed immunoelectrophoresis may be useful in 


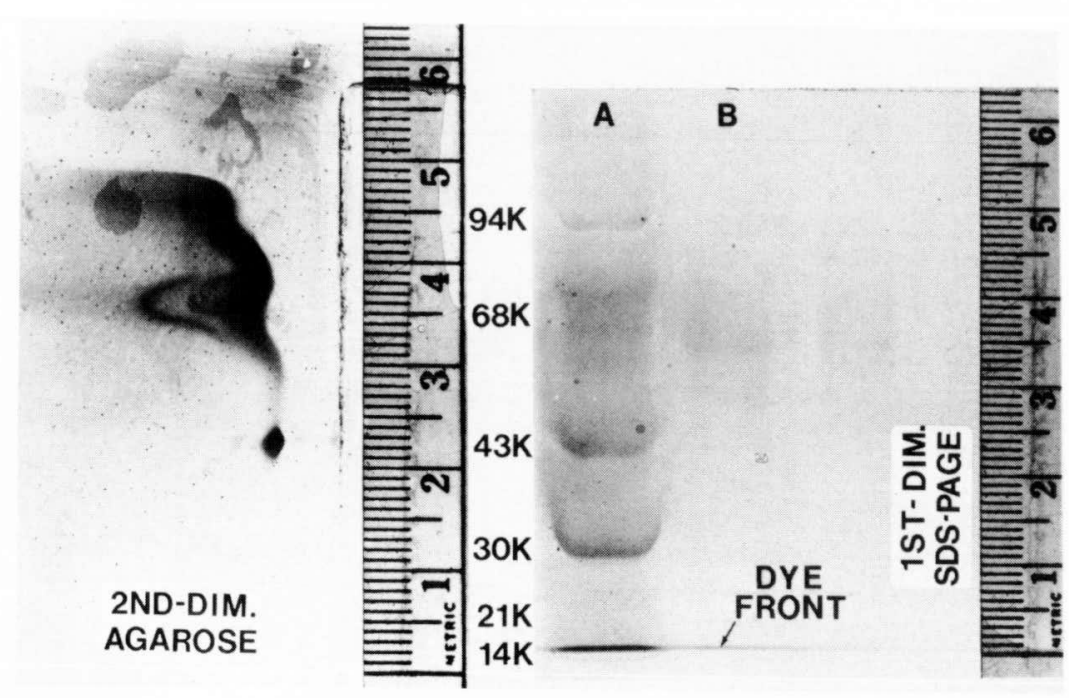

Fig. 7. Detection of partially purified, extracted antigen by polyacrylamide-agarose gel twodimensional immunoelectrophoresis. Fractions 21-30 from the Ultragel AcA 44 column were pooled, concentrated, and subjected to electrophoresis in SDS polyacrylamide. The gel was sliced vertically and one strip subjected to immunoelectrophoresis into agarose containing antiLea-1-74 serum, to identity the position of the extracted antigen (F). The other strip, containing extracted antigen (lane B) and a mixture of low molecular weight standards (lane A) was stained with Coomassie Brilliant Blue. Zero position on the ruler is the bottom of the resolving gel.

such studies (AXELSON and BROCK, 1972).

\section{Acknowledgements}

We gratefully thank those individuals who kindly supplied bacterial strains used in this study and $\mathrm{S}$. Kaattari for his critical review of this manuscript.

This report is based upon work supported by the U.S. Department of Agriculture under Agreement No. 159-2411-1-2-056-0. Oregon Agricultural Experiment Station Technical Paper No. 7255.

\section{References}

Austin, B. and C. J. Rodgers (1980): Diversity among strains causing bacterial kidney disease in salmonid fish. Curr. Microbiol., 3, 231-235.

Axelson, N. H. and E. Brock (1972): Identification and quantitation of antigens and antibodies by means of quantitative immunoelectrophoresis. A survey of methods. J. Immunol. Methods, 1, 109-121.

BRADFORD, M. (1976): A rapid and sensitive method for the quantitation of microgram quantities of protein utilizing the principle of protein-dye binding. Anal. Biochem., 72, 248-254.

Bullock, G. L., B. R. Griffin, and H. M. Stuckey (1980): Detection of Corynebacterium salmoninus by direct fluorescent antibody test. Can. J. Fish. Aquat. Sci, 37, 719-721.

Bullock, G. L., H. M. Stuckey, and P. K. Chen (1974): Corynebacterial kidney disease of salmonids: Growth and serological studies on the causative bacterium. Appl. Microbiol., 28, 811-814.

Chen, P. K., G. L. Bullock, H. M. Stuckey, and A. C. Bullock (1974): Serological diagnosis and detection of corynebacterial kidney disease in salmonids. J. Fish. Res. Board Can., 31, 1939-1940.

EVELYN, T. P. T. (1977): An improved growth medium for the kidney disease bacterium and some notes on using the medium. Bull. Off. Int. Epizoot., 87, 511-513.

FrYer, J. L. and J. E. SANDERS (1981): Bacterial kidney disease of salmonid fish. Ann. Rev. Microbiol., 35, 273 298.

Hiu, S. F., R. A. Holt, N. L. SRiranganathan, R. J. SeIDler, and J. L. Fryer (1984): Lactobacillus piscicola, a new species from salmonid fish. Int. J. Syst. Bacteriol., 34, 393-400.

Kimura, T., Y. Ezura, K. Tajima, and M. Yoshimizu (1978): Serological diagnosis of bacterial kidney disease of salmonids (BKD): immunodiffusion test by heat stable antigen extracted from infected kidney. Fish Pathol., 13, 103-108.

LaEmmLi, U. K. (1970): Cleavage of structural proteins during the assembly of the head of bacteriophage T4. Nature, 222, 680-685. 
O'Leary, P. J., J. S. Rohovec, J. E. SAnders, and J. L. FRYER (1982): Serotypes of Yersinia ruckeri and their immunogenic properties. Oregon State University Sea Grant College Program. Publication No. ORESU-T-82$001.15 \mathrm{p}$.

Paterson, W. D., S. P. Lall, and D. Desautels (1981): Studies on bacterial kidney disease in Atlantic salmon (Salmo salar) in Canada. Fish Pathol., 15, 283-292.

SANDERS, J. E. and J. L. Fryer (1980): Renibacterium salmoninarum gen. nov., sp. nov., the causative agent of bacterial kidney disease in salmonid fishes. Int. J. Syst. Bacteriol., 30, 496-502.

ThIRKILl, C. E. and G. E. KenNy (1974): Serological comparison of five arginine-utilizing Mycoplasma species by two-dimensional immunoelectrophoresis. Infect. Immun., 10, 624-632.

Young, C. L. and G. B. Chapman (1978): Ultrastructural aspects of the causative agent and renal histopathology of bacterial kidney disease in brook trout (Salvelinus fontinalis). J. Fish. Res. Board Can., 35, 1234-1248. 